\title{
Topical Anti-Inflammatory Activity of Calea prunifolia HBK (Asteraceae) in the TPA Model of Mouse Ear Inflammation
}

\author{
Milton Gómez* and Juan F. Gil \\ Grupo de Búsqueda de Principios Bioactivos, Programa de Química, Universidad del Quindío, Armenia, Colombia
}

O estudo fitoquímico de Calea prunifolia identificou dois compostos derivados de $p$-hidroxiacetofenona, a 1-(2-hidroxi-5-(1-metoxietil)fenil)-3-metilbut-2-en-1-ona apresentou atividade anti-inflamatória satisfatória (58.33\%), tratando-se de um produto natural. Apesar dos dois compostos derivados serem estruturalmente semelhantes, a atividade anti-inflamatória da 1-(2-hidroxi-5-metoxifenil)-3-metilbut-2-en-1-ona não foi significativa (2.08\%). $\mathrm{O}$ ensaio foi realizado em modelo de inflamação induzido por 12- $O$-tetra-decanoilforbol-13-acetato (TPA) em orelha de ratos. $\mathrm{O}$ controle positivo foi testado com indometacina e foram ensaiados controles negativos tratados somente com o veículo. Estes resultados possibilitam a identificação de um grupo farmacóforo que através de estudos de modelagem molecular e síntese orgânica podem resultar em compostos com atividade anti-inflamatória melhorada.

Phytochemical study of Calea prunifolia HBK identified two compounds derived from p-hydroxyacetophenone, the 1-(2-hydroxy-5-(1-methoxyethyl)phenyl)-3-methylbut-2-en-1-one showed a satisfactory anti-inflammatory activity $(58.33 \%)$, when considering that this is a natural product. Although the two derived compounds are structurally similar, the anti-inflammatory activity of 1-(2-hydroxy-5-methoxyphenyl)-3-methylbut-2-en-1-one was not significant $(2.08 \%)$. The test was conducted in a model of inflammation induced by topical application of 12-O-tetradecanoylphorbol-13-acetate (TPA) in the ear of mice. The positive control was tested with indomethacin and the negative control was done only with vehicle. These results allow the identification of a pharmacophore group that through molecular modeling studies and organic synthesis can result in compounds with improved anti-inflammatory activity.

Keywords: Calea prunifolia HBK, anti-inflammatory activity, mouse edema

\section{Introduction}

The inflammatory process is a physiological response to injuries, traumas, bone fracture, hypersensitivity reactions and other diseases, ${ }^{1,2}$ and causes an accumulation of fluid, blood cells, cellular and extracellular constituents of connective tissue and produce pain. ${ }^{3}$ Many current antiinflammatory drugs are synthetic, and their toxicity and reappearance of symptoms after discontinuation are a common problem. ${ }^{4,5}$ These untoward effects restrict their long-term use. ${ }^{6}$ Hence, there is a constant demand for better therapeutic alternatives. For this reason, the search for new anti-inflammatory drugs is directed to the research of new hit molecules in plants traditionally used as medicinal, ${ }^{7-12}$ which can be modified using organic synthesis to improve activity.

The genus Calea is part of the Asteraceae family, which is known for its diverse and important pharmacological

*e-mail: miltongoba@uniquindio.edu.co activities: antimicrobial, vasodilating activity and others. ${ }^{13}$ In the searching for compounds, non-steroidal antiinflammatory agents/analgesics (NSAIDs) show a promising potential because this activity in several genus of plants of this family have been widely reported. ${ }^{1,14-16}$ The reason for this property is the secondary metabolites that these plants possess. It has been particularly reported in studies involving the Calea prunifolia HBK the presence of metabolites like as sesquiterpene, acorane, ${ }^{17}$ eudesmanolides, guaianolides, ${ }^{18}$ flavonoids and other. ${ }^{19}$ So, the aim of this work is to evaluate the anti-inflammatory activity of Calea prunifolia HBK and the isolation of an active agent.

\section{Experimental}

Vegetal material

Calea prunifolia HBK was collected from the Ocaña (Norte de Santander, Colombia) and a voucher specimen 
(HBK: COL468655) was deposited in the Herbarium of the Universidad Nacional de Colombia (HUN).

\section{General procedure}

${ }^{1} \mathrm{H},{ }^{13} \mathrm{C}$ and 2D nuclear magnetic resonance (NMR) spectra of isolated compounds were recorded on a Bruker DRX 300, operating at $300 \mathrm{MHz}$ for ${ }^{1} \mathrm{H}$ and $75 \mathrm{MHz}$ for ${ }^{13} \mathrm{C}$. Chemical shifts $(\delta)$ were reported in ppm and coupling constants $(J)$ in $\mathrm{Hz}, \mathrm{CDCl}_{3}$ was used as solvent and internal standard. In the direct infusion mass spectrometry (DIMS) technique, the sample was directly injected into the electrospray ionization (ESI) source in the mass spectrometer equipment with ion trap detector (Agilent model SL 6300 series). ESI-MS spectra (positive or negative mode) were acquired from $\mathrm{m} / \mathrm{z}, 100-400$. The following parameters were used: capillary temperature of $275^{\circ} \mathrm{C}$, capillary voltage of $20 \mathrm{~V}$, spray voltage of $5 \mathrm{kV}$, tube lens of $-5 \mathrm{~V}$. UV-Visible spectra were recorded in a ThermoScientific Genesys 10S Spectrometer. Infrared spectra were acquired in $\mathrm{KBr}$ with a ThermoNicolet Avatar 330. Silica gel 60 (200-300 mesh, Merck) was used for all separations. While silica gel $60 \mathrm{~F}_{254}$ (Merck) was used for analytical thin layer chromatography (TLC), the compounds were detected under UV light $(254,366 \mathrm{~nm})$ and by spraying with vanillin/ $\mathrm{H}_{3} \mathrm{PO}_{4}$ followed by heating.

\section{Extraction and isolation}

Dried and ground leaves from Calea prunifolia HBK were exhaustively extracted by percolation with EtOH at room temperature and the extract was concentrate under vacuum and at $35^{\circ} \mathrm{C}$. The crude extract was chromatographed on a silica gel column with $\mathrm{CH}_{2} \mathrm{Cl}_{2}$ obtaining five fractions (F1-F5) followed by $\mathrm{CH}_{2} \mathrm{Cl}_{2}$ :EtOAc mixtures of increasing polarity. Four fractions were collected (F6-F9), the last fraction was obtained using $\mathrm{MeOH}(\mathrm{F} 10), 500 \mathrm{~mL}$ of solvent was used in each fraction. Fractions 2-3 yielded compound $\mathbf{1}$ and fractions 4-5 gave compound $\mathbf{2}$.

1-(2-Hydroxy-5-(1-methoxyethyl)phenyl)-3-methylbut2-en-1-one (1)

Yellow crystal; UV $(\mathrm{MeOH}) \lambda_{\max } / \mathrm{nm}(\log \varepsilon): 220$ (4.04), 274 (4.13), 344 (3.56); IR (KBr) $v_{\max } / \mathrm{cm}^{-1}: 3436$ $(\mathrm{OH}), 1638(\mathrm{C}=\mathrm{O}), 1580$ (o-hidroxyacetone), $1486(\mathrm{Ar})$; DIMS $m / z$ (relative intensity): $256.9[\mathrm{M}+\mathrm{Na}]^{+}(100), 235.0$ $[\mathrm{M}+\mathrm{H}]^{+}(10)$ in positive mode and $232.8[\mathrm{M}-\mathrm{H}]^{-}(100)$ in negative mode (calc. for $\mathrm{C}_{14} \mathrm{H}_{18} \mathrm{O}_{3}: 234.0$ ); for ${ }^{1} \mathrm{H}$ and ${ }^{13} \mathrm{C}$ NMR spectroscopic data, see Table 1.

1-(2-Hydroxy-5-methoxyphenyl)-3-methylbut-2-en-1-one (2)

Yellow oil; UV (MeOH) $\lambda_{\max } / \mathrm{nm}(\log \varepsilon): 220$ (4.04), 272 (4.08), 372 (3.58); IR (KBr) $v_{\max } / \mathrm{cm}^{-1}: 3513(\mathrm{OH})$, $1643(\mathrm{C}=\mathrm{O}), 1585$ (o-hidroxyacetone), $1488 \mathrm{~cm}^{-1}(\mathrm{Ar})$; DIMS $m / z$ (relative intensity): $228.9[\mathrm{M}+\mathrm{Na}]^{+}(100), 206.9$ $[\mathrm{M}+\mathrm{H}]^{+}(10)$ in positive mode and $204.8[\mathrm{M}-\mathrm{H}]^{-}(100)$ in negative mode (calc. for $\mathrm{C}_{12} \mathrm{H}_{14} \mathrm{O}_{3}: 206,24$ ); for ${ }^{1} \mathrm{H}$ and ${ }^{13} \mathrm{C}$ NMR spectroscopic data, see Table 1.

\section{Animals}

Female ICR mice (25-30 g) were obtained from animal facility at the Department of Pharmacy of the

Table 1. ${ }^{1} \mathrm{H}$ and ${ }^{13} \mathrm{C}$ NMR data of compounds $\mathbf{1}$ and $\mathbf{2}\left(\mathrm{CDCl}_{3}, \delta\right.$ values $)$

\begin{tabular}{|c|c|c|c|c|}
\hline \multirow{2}{*}{ Position } & \multicolumn{2}{|c|}{1} & \multicolumn{2}{|c|}{2} \\
\hline & ${ }^{1} \mathrm{H} \delta \mathrm{m}(J)$ & ${ }^{13} \mathrm{C} \delta \mathrm{m}(J)$ & ${ }^{1} \mathrm{H} \delta \mathrm{m}(J)$ & ${ }^{13} \mathrm{C} \delta \mathrm{m}(J)$ \\
\hline 1 & & $164.74 \mathrm{~s}$ & & $157.89 \mathrm{~s}$ \\
\hline 2 & & $120.8 \mathrm{~s}$ & & $119.64 \mathrm{~s}$ \\
\hline 3 & $7.5 \mathrm{~d}(2.0)$ & $127.7 \mathrm{~d}$ & $7.2 \mathrm{~d}(2.29)$ & $113.3 \mathrm{~d}$ \\
\hline 4 & & $133.9 \mathrm{~s}$ & & $152.2 \mathrm{~s}$ \\
\hline 5 & $7.2 \mathrm{dd}(2.0 ; 8.6)$ & $134.3 \mathrm{~d}$ & $7.0 \mathrm{dd}(2.29 ; 9.02)$ & $124.18 \mathrm{~d}$ \\
\hline 6 & $6.80 \mathrm{~d}(8.6)$ & $118.9 \mathrm{~d}$ & $6.80 \mathrm{~d}(9.02)$ & $119.49 \mathrm{~d}$ \\
\hline 7 & $4.2 \mathrm{q}(6.3)$ & $80.2 \mathrm{~d}$ & & \\
\hline 8 & $1.2 \mathrm{~d}(6.3)$ & $25.2 \mathrm{q}$ & & \\
\hline 9 & & $196.2 \mathrm{~s}$ & & $196.17 \mathrm{~s}$ \\
\hline 10 & $6.6 \mathrm{~s}$ & $120.4 \mathrm{~d}$ & $6.6 \mathrm{~s}$ & $120.56 \mathrm{~d}$ \\
\hline 11 & & $157.19 \mathrm{~s}$ & & $158.57 \mathrm{~s}$ \\
\hline 12 & $1.99 \mathrm{~s}$ & $29.0 \mathrm{q}$ & $1.9 \mathrm{~d}(1.2)$ & $28.1 \mathrm{q}$ \\
\hline 13 & $2.15 \mathrm{~s}$ & $22.5 \mathrm{q}$ & $2.1 \mathrm{~d}(1.2)$ & $21.8 \mathrm{q}$ \\
\hline $\mathrm{OCH}_{3}$ & $3.15 \mathrm{~s}$ & $56.0 \mathrm{q}$ & $3.7 \mathrm{~s}$ & $56.34 \mathrm{q}$ \\
\hline
\end{tabular}

${ }^{13} \mathrm{C}=75 \mathrm{MHz},{ }^{1} \mathrm{H}=300 \mathrm{MHz} ; \delta / \mathrm{ppm}, \mathrm{m}=$ multiplicity and $J / \mathrm{Hz}$. 
Universidad Nacional de Colombia. The experiments were conducted in accordance with the guidelines of the Ethics Committee of the Universidad Nacional de Colombia and the international ethical guidelines for the care and use of experimental animals..$^{20}$ The female ICR mice were fed according to a standard diet, food and water access was ad libitum, and kept under controlled climatic conditions, photoperiods equal to $12 \mathrm{~h}$ of light with environmental temperature at $21^{\circ} \mathrm{C}$. The test included the substances under study. It was administrated for the negative control group only the vehicle and the positive control group received indomethacin as reference drug.

Ear edema in mice induced by TPA (12-O-tetradecanoylphorbol-13-acetate)

Edema was induced in both ears of each mouse by the topical application of $2.5 \mu \mathrm{g}$ TPA dissolved in $20 \mu \mathrm{L}$ of acetone to both the inner and outer ear surfaces $(10 \mu \mathrm{L}$ per side). Later, the substances under testing (extracts and compounds) dissolved in acetone were applied in the right ear in a concentration of $500 \mu \mathrm{g}$ per ear, using indomethacin as reference substance in all cases, the left ear was negative control, receiving only vehicle. Four hours later, mice were sacrificed and a plug $(\varnothing 6 \mathrm{~mm})$ was removed from both the treated and the untreated ears. The weight difference between right and left ears was taken as an expression of edema. The results were expressed as edema and as percentage of inhibition versus the control group. ${ }^{3,12,19,22}$

\section{Results and Discussions}

\section{Structural elucidation}

\section{1-(2-Hydroxy-5-(1-methoxyethyl)phenyl)-3-methylbut- 2-en-1-one (1)}

The DIMS spectrum showed a quasi-molecular ion peak at $\mathrm{m} / \mathrm{z} 235$ and 233 in $[\mathrm{M}+\mathrm{H}]^{+}$and $[\mathrm{M}-\mathrm{H}]^{-}$mode, respectively, corresponding to a molecular weight of $234 \mathrm{~m} / \mathrm{z}$, compatible with the molecular formula $\mathrm{C}_{14} \mathrm{H}_{18} \mathrm{O}_{3}$.

The ${ }^{1} \mathrm{H}$ NMR (Table 1) and homonuclear correlation spectroscopy (COSY) NMR spectra showed the presence of an $\mathrm{AB}$ system at $\delta 7.5(\mathrm{~d}, J 2.0 \mathrm{~Hz}, \mathrm{H}-3), 7.2$ (dd, $J 8.6$ and $2.0 \mathrm{~Hz}, \mathrm{H}-5)$ and $6.80(\mathrm{~d}, J 8.6 \mathrm{~Hz}, \mathrm{H}-6)$; a vinyl hydrogen at $\delta 6.6 \mathrm{ppm}$ (s, H-10); a methoxyl at $\delta 3.15$ (s); two singlet at chemical shift 2.15 (H-13) and 1.99 (H-12), indicative of methyl groups in a isoprene system, and another methyl group at $\delta 1.2 \mathrm{ppm}(\mathrm{d}, J 6,3 \mathrm{~Hz}, \mathrm{H}-8)$ coupled in COSY NMR to a methine signal at $\delta 4.2$ (q, $J$ $6.3 \mathrm{~Hz}, \mathrm{H}-7$ ). The ${ }^{13} \mathrm{C}$ NMR spectrum (Table 1) showed four signals corresponding to $\mathrm{CH}_{3}$ group with chemical shifts $\delta 56.0,29.0,25.2$ and 22.5. The one corresponds to a methoxyl group as substituent at C-7, the third to methyl in C-8, finally, the second and four correspond to two methyl groups on double bond of isoprene system C-12 and C-13. The signal at $\delta 196.2 \mathrm{ppm}$ was attributed to the carbonyl carbon, the signals $\delta 164.74,134.3,133.9,127.7,120.8$ and 118.9 correspond to a six aromatic carbon atoms in a benzene ring. Besides this, the structure was elucidated with the help of 2D NMR techniques: heteronuclear single-quantum correlation spectroscopy (HMQC) and heteronuclear multiple-bond correlation spectroscopy (HMBC). The HMBC experiment showed correlations of C-1 $(\delta$ 164.74) with H-3 $(\delta 7.5)$ and H-5 $(\delta 7.2)$; C-2 $(\delta$ 120.8) with H-6 ( $\delta 6.80)$ and H-3 $(\delta 7.5)$, similarly, H-7 $(\delta 4.2)$ correlates with the C-4 ( $\delta 133.9)$ and C-5 ( $\delta$ 134.3). The position of de quaternary carbon $\mathrm{C}-4$ was obtained through $\mathrm{HMBC}$ correlation with the $\mathrm{CH}_{3}$ at $(\delta 1.2)$.

\section{1-(2-Hydroxy-5-methoxyphenyl)-3-methylbut-2-en-1-one} (2)

Comparing the spectroscopic data of the compound $\mathbf{1}$ and 2 and the literature, ${ }^{18,22,23}$ it was possible to determine the structure of the second, with some differences between both. In the compound $\mathbf{2}$, the methoxyl group is bonded directly to aromatic ring $\mathrm{C}-4$, that way, this carbon showed a higher chemical shift, C-4 ( $\delta$ 152.2), affecting the $\mathrm{C}-3$ with $\delta$ 113.3. The other difference was the absence of carbons C-7 and C-8. The structures are showed in Figure 1.

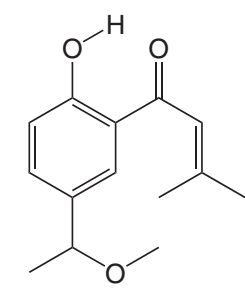

(1)

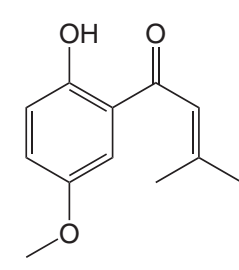

(2)
Figure 1. Structures of compounds $\mathbf{1}$ and $\mathbf{2}$.

These compounds have been previously isolated from Calea uniflora and Calea peckii, $\mathbf{1}$ and $\mathbf{2}$ respectively, as well as compound $\mathbf{1}$ has been tested on their biological activity against trypanosoma parasites and fungi.

\section{Anti-inflammatory activity}

The difference between the ear weights of the one only treated with TPA and the one treated with the compounds indicates the percentage of inhibition (I / \%) of the inflammatory action (Table 2). In this sense, when it is compared the weight of the ears of untreated mice $(8.0 \mathrm{mg})$, the weight of those treated with compound $\mathbf{1}(3.3 \mathrm{mg})$, 
Table 2. Anti-inflammatory activity results

\begin{tabular}{lcccc}
\hline \multirow{2}{*}{$\mathrm{n}$} & Control & Indomethacin & \multicolumn{2}{c}{ Compounds } \\
\cline { 2 - 5 } & & & $\mathbf{1}$ & $\mathbf{2}$ \\
\cline { 2 - 5 } & $\Delta \mathrm{p}^{\mathrm{a}} / \mathrm{mg}$ & $\Delta \mathrm{p}^{\mathrm{a}} / \mathrm{mg}$ & 2 & 4 \\
1 & 5 & 0 & 5 & 11 \\
2 & 4 & 3 & 3 & 5 \\
3 & 16 & 0 & 5 & 9 \\
4 & 7 & 4 & 3 & 10 \\
5 & 7 & 0 & 2 & 8 \\
6 & 9 & 2 & $3.3^{\mathrm{c}} \pm 1.2$ & $7.8^{\mathrm{c}} \pm 2.5$ \\
\hline $\mathrm{M}+\mathrm{SD}^{\mathrm{b}} / \mathrm{mg}$ & $8.0^{\mathrm{c}} \pm 3.9$ & $1.5^{\mathrm{c}} \pm 1.6$ & 58.33 & 2.08 \\
$\mathrm{I} / \%{ }^{\mathrm{d}}$ & 0 & 81.25 & & 5 \\
\hline
\end{tabular}

${ }^{\mathrm{a}} \Delta \mathrm{p}=$ Differences of weight between ears; ${ }^{\mathrm{b}}$ mean \pm standard deviation $(\mathrm{n}=6) ;{ }^{\mathrm{c}} p<0.05$ ANOVA, statistically significant compared to control; ${ }^{\mathrm{d}} \mathrm{I} / \%=$ percentage of inhibition.

giving 58.33\% of inhibition. This result when compared with the weight of ears of mice treated with indomethacin $(1.5 \mathrm{mg}$ ) with an anti-inflammatory activity of $81.25 \%$ (of inhibition), it is not very appreciable. On the other hand, the activity is considered high when comes to a natural product.

The TPA ear edema model in mice is useful to testing pharmaceutical agents or natural products with prospective anti-inflammatory activity involved in the inhibition of arachidonic acid pathway. ${ }^{19,24}$ Products of arachidonic acid metabolism, such as $\mathrm{PGI}_{2}$ and $\mathrm{LTB}_{4}$, increase vascular permeability leading to edema during the inflammatory response. So, the use of inhibitors of phospholipase framed in the synthesis of AA, such as corticoids, has marked antiinflammatory action. Likewise, compounds of inhibiting cyclooxygenase (COX) and lipoxygenase (LOX) enzymes have been shown to inhibit TPA induced inflammation..$^{19,25}$

The main mechanism of action of non-steroidal antiinflammatory agents/analgesics (NSAIDs) is involved in the inhibition of COX/LOX enzymes, in addition, some aromatic compounds, such as acetylsalicylic acid (which has a mode of anti-inflammatory action by irreversible suppression of the enzyme COX 1), hamper the synthesis of prostaglandins by decreasing of the inflammation. Similarly, some acrylic acids, such as 4-hydroxybenzene derivatives, are able to engage with the active site of the cyclooxygenase and lipoxygenase enzymes. ${ }^{26}$

Therefore, it is possible to presume that the antiinflammatory action shown by compound $\mathbf{1}$ is due to the intervention of this compound to the COX or LOX enzymes involved in the synthesis of prostaglandins resulting in the decreased inflammatory event.

Taking into account the mode of action of this molecule and the type of used assay by testing the compounds, we propose the possible mode of action of the molecule 1, which suggests an irreversible attachment in an active site of an enzyme involved in inflammation, a process that is restricted in the molecule 2.

\section{Conclusions}

Assuming that the difference between the molecules is minimal, the compounds isolated from Calea prunifolia HBK are likely to be synthetically modified to enhance anti-inflammatory activity with the aim of achieving an active and safe compound.

\section{Supplementary Information}

The spectra are provided as Supplementary Information and available free of charge at http://jbcs.sbq.org.br as PDF file.

\section{Acknowledgments}

The authors thank the Universidad Nacional de Colombia (Bogotá, Colombia) and the Universidad del Quindío (Armenia, Colombia).

\section{References}

1. Castelucci, S.; Rogerio, A.; Ambrosio, S.; Arakawa, N.; Lira, S.; Faccioli, L.; Costa, F.; J. Ethnopharmacol. 2007, 112, 192.

2. Gené, R. M.; Cartaña, C.; Adzet, T.; Marán, E.; Parella, T.; Canigueral, S.; Planta Med. 1996, 62, 232.

3. Ojewole, J. A. O.; J. Ethnopharmacol. 2007, 113, 338.

4. Armstrong, E. P.; Malone, D. C.; Clin. Ther. 2003, 25, 1.

5. Hull, M. A.; Gardner, S. H.; Hawcroft, G.; Cancer. Treat. Rev. 2003, 29, 309.

6. Raghav, S.; Gupta, B.; Agrawal, C.; Goswami, K.; Das, H.; J. Ethnopharmacol. 2006, 104, 234.

7. Sosa, S.; Balick, M. J.; Arvigo, R.; Esposito, R. G.; Pizza, C.; Altinier, G.; Tubaro, A.; J. Ethnopharmacol. 2002, 81, 211.

8. Flodmark, C. A.; Bruhn, J. G.; Bohlin, L.; Drug Discovery Today 2001, 6, 455.

9. Abad, M. J.; Bermejo, P.; Carretero, E.; Martínez-Acitores, C.; Noguera, B.; Villar, A.; J. Ethnopharmacol. 1996, 55, 63.

10. Ruppelt, B. M.; Pereira, E. F. R.; Gonçalves, L. C.; Pereira, N. A.; Mem. Inst. Oswaldo Cruz 1991, 86, 203.

11. Fawole, O. A.; Ndhlala, A. R.; Amoo, S. O.; Finnie, J. F.; Van Staden, J.; J. Ethnopharmacol. 2009, 123, 237.

12. Amresh, G.; Reddy, G.; Rao, C.; Singh, P.; J. Ethnopharmacol. 2007, 110, 526.

13. Ingrid L. Onzaga; Rincón, J.; Guerrero, M. F.; Colomb. Med. 2008, 39, 33 . 
14. dos Santos, D. A.; Fukui, M. D. J.; Nanayakkara, N. P. D.; Khan, S. I.; Sousa, J. P. B.; Bastos, J. K.; Andrade, S. F.; Silva Filho, A. A.; Quintão, N. L. M.; J. Ethnopharmacol. 2010, 127, 543.

15. Alves, K.; Gobboneto, L.; Lopes, N.; Biochem. Syst. Ecol. 2008, $36,434$.

16. Hamburger, M.; Adler, S.; Baumann, D.; Förg, A.; Weinreich, B.; Fitoterapia 2003, 74, 328.

17. Castro, V.; Jakupovic, J.; Bohlmann, F.; J. Nat. Prod. 1984, 47, 802.

18. Castro, V.; Tamayo-Castillo, G.; Jakupovic, J.; Phytochemistry 1989, 28, 2415.

19. Bralley, E. E.; Greenspan, P.; Hargrove, J. L.; Wicker, L.; Hartle, D. K.; J. Inflamm. 2008, 5, 1.

20. http://www.dib.unal.edu.co/promocion/etica_res_8430_1993. pdf accesed in August 2011.
21. Franco, L. A.; Matiz, G. E.; Calle, J.; Pinzón, R.; Ospina, L. F. Biomédica 2010, 27, 110.

22. do Nascimento, A. M.; Salvador, M. J.; Candido, R. C.; de Albuquerque, S.; de Oliveira, D. C. R.; J. Pharm. Pharmacol. 2004, 56, 663.

23. Ober, A. G.; Urbatsch, L. E.; Fischer, N. H.; Phytochemistry 1985, 24, 795.

24. Puigneró, V.; Turull, A.; Queralt, J.; Inflammation 1998, 22, 307.

25. Fujimori, S.; Seo, T.; Gudis, K.; Ehara, A.; Kobayashi, T.; Mitsui, K.; Yonezawa, M.; Tanaka, S.; Tatsuguchi, A.; Sakamoto, C.; Gastrointest. Endosc. 2009, 69, 1339.

26. Mao, J.-L.; Ran, X.-K.; Tian, J.-Z.; Jiao, B.; Zhou, H.-L.; Chen, L.; Wang, Z.-G.; Bioorg. Med. Chem. Lett. 2011, 21, 1549.

Submitted: March 31, 2011 Published online: September 6, 2011 


\section{Supplementary Information}

Topical Anti-Inflammatory Activity of Calea prunifolia HBK (Asteraceae) in the TPA Model of Mouse Ear Inflammation

\section{Milton Gómez* and Juan F. Gil}

Grupo de Búsqueda de Principios Bioactivos, Programa de Química,

Universidad del Quindío, Armenia, Colombia

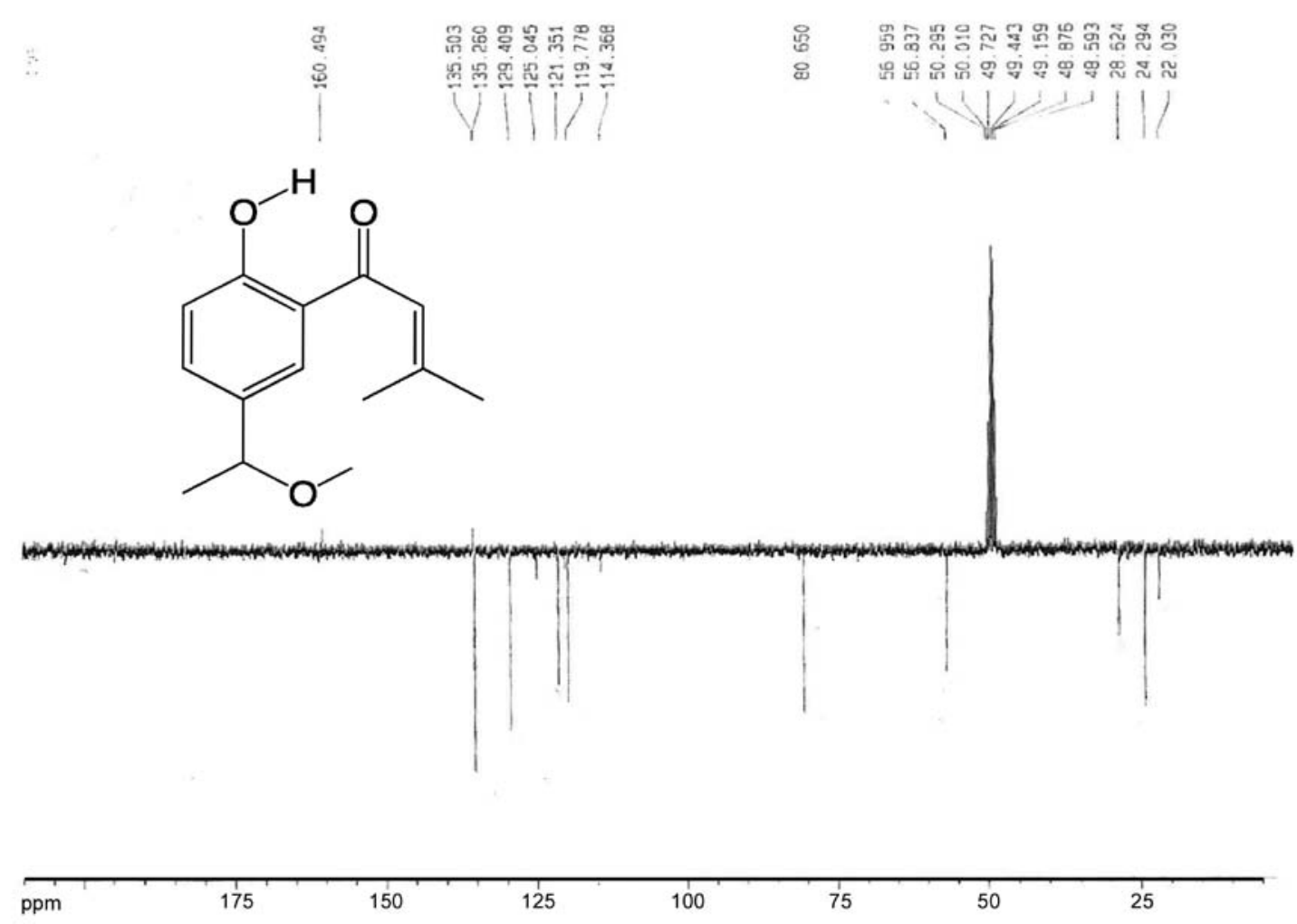

Figure S1. J-Mod NMR spectrum $\left(\mathrm{CDCl}_{3}\right)$ of compound $\mathbf{1}$. 


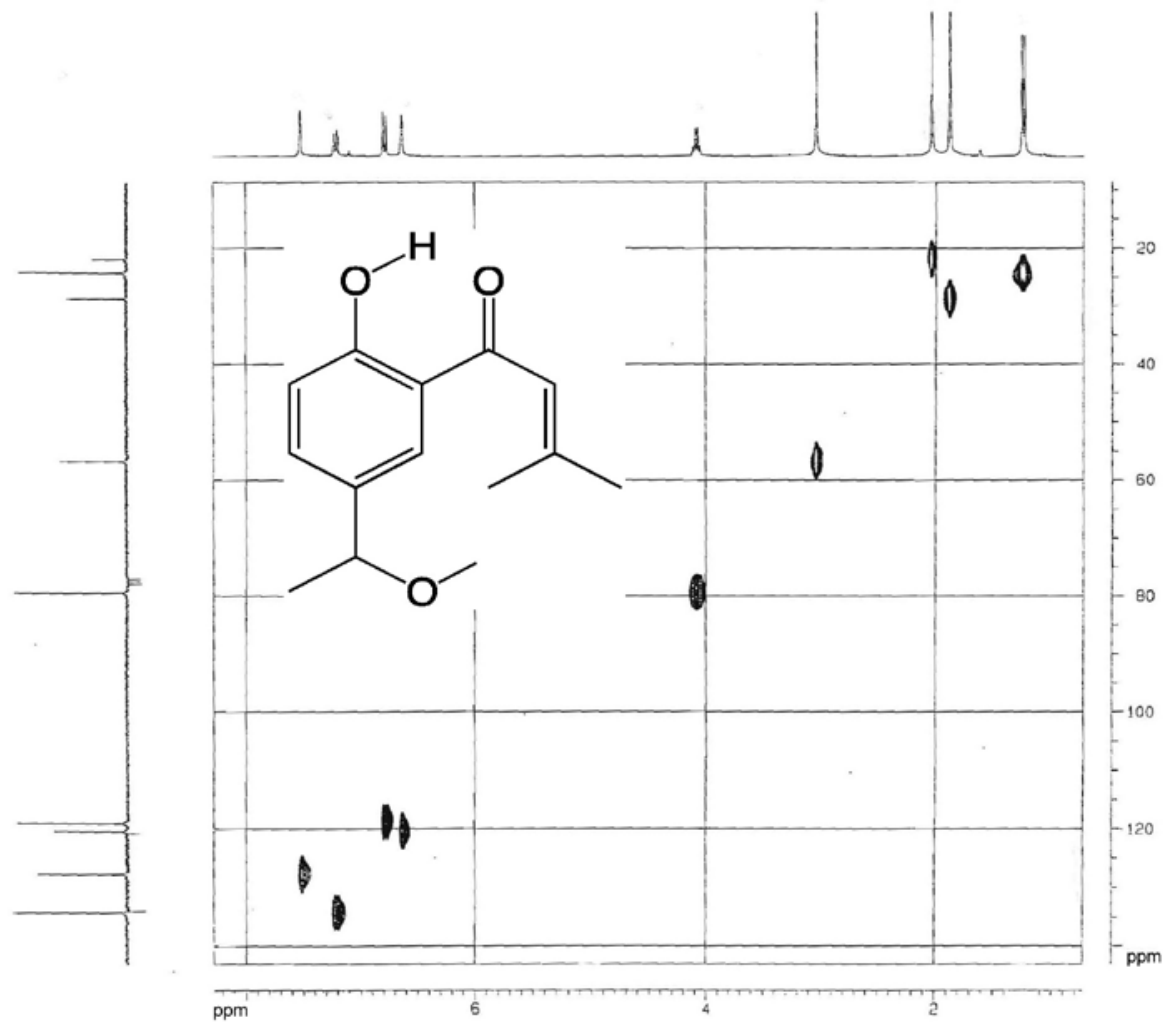

Figure S2. HMQC NMR spectrum $\left(\mathrm{CDCl}_{3}\right)$ of compound $\mathbf{1}$.

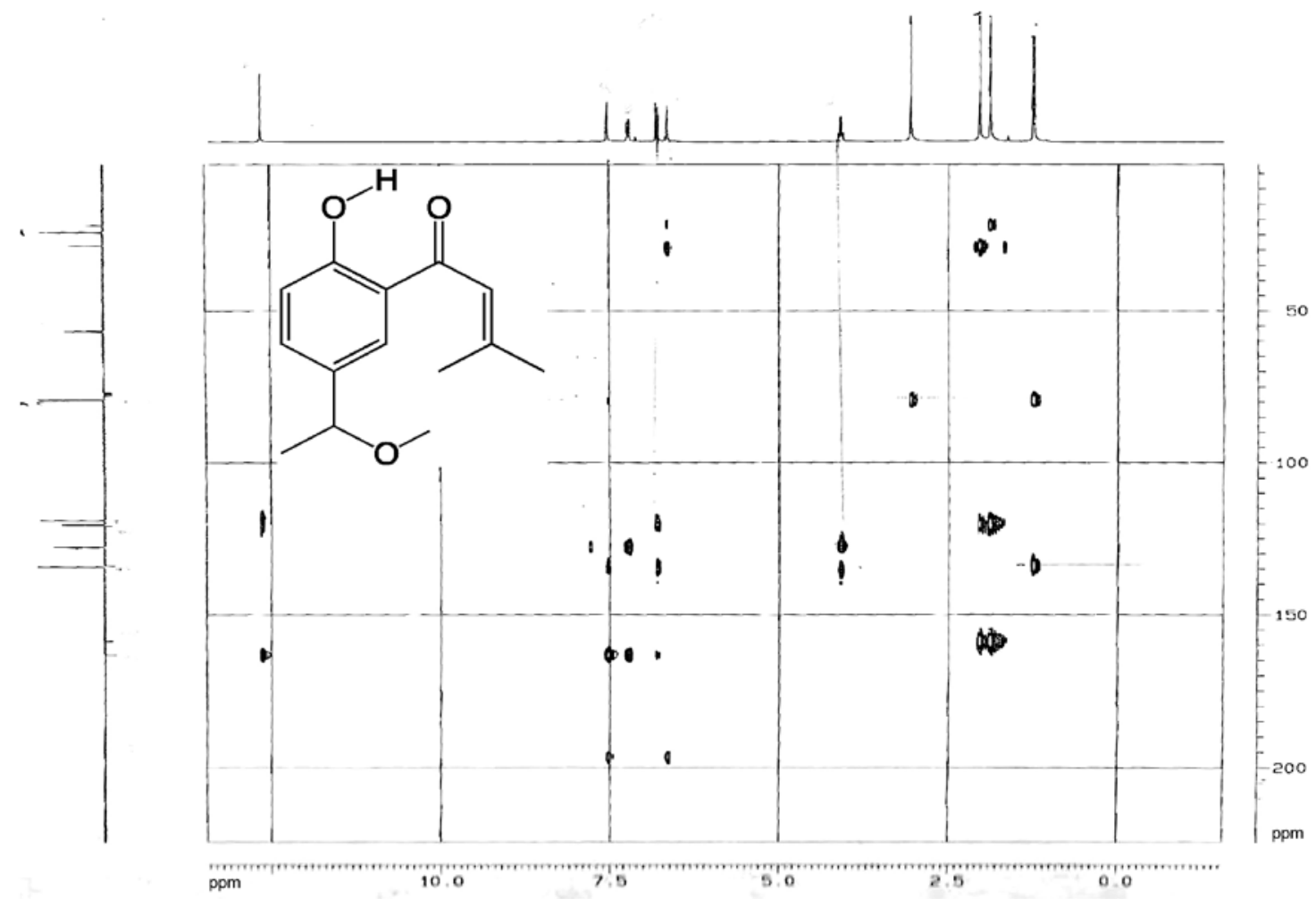

Figure S3. HMBC NMR spectrum $\left(\mathrm{CDCl}_{3}\right)$ of compound $\mathbf{1}$. 


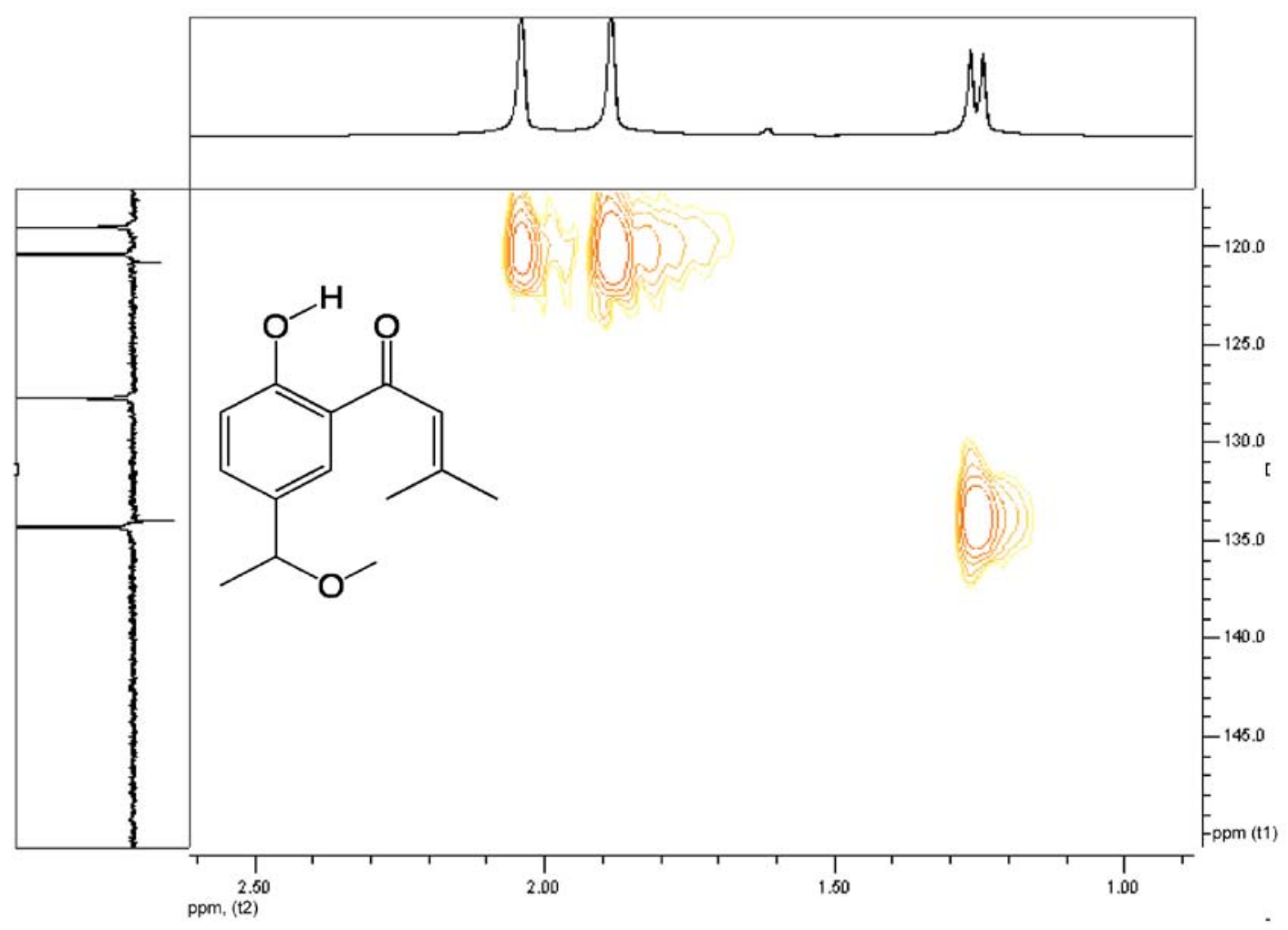

Figure S4. HMBC expansion NMR spectrum $\left(\mathrm{CDCl}_{3}\right)$ of compound $\mathbf{1}$.

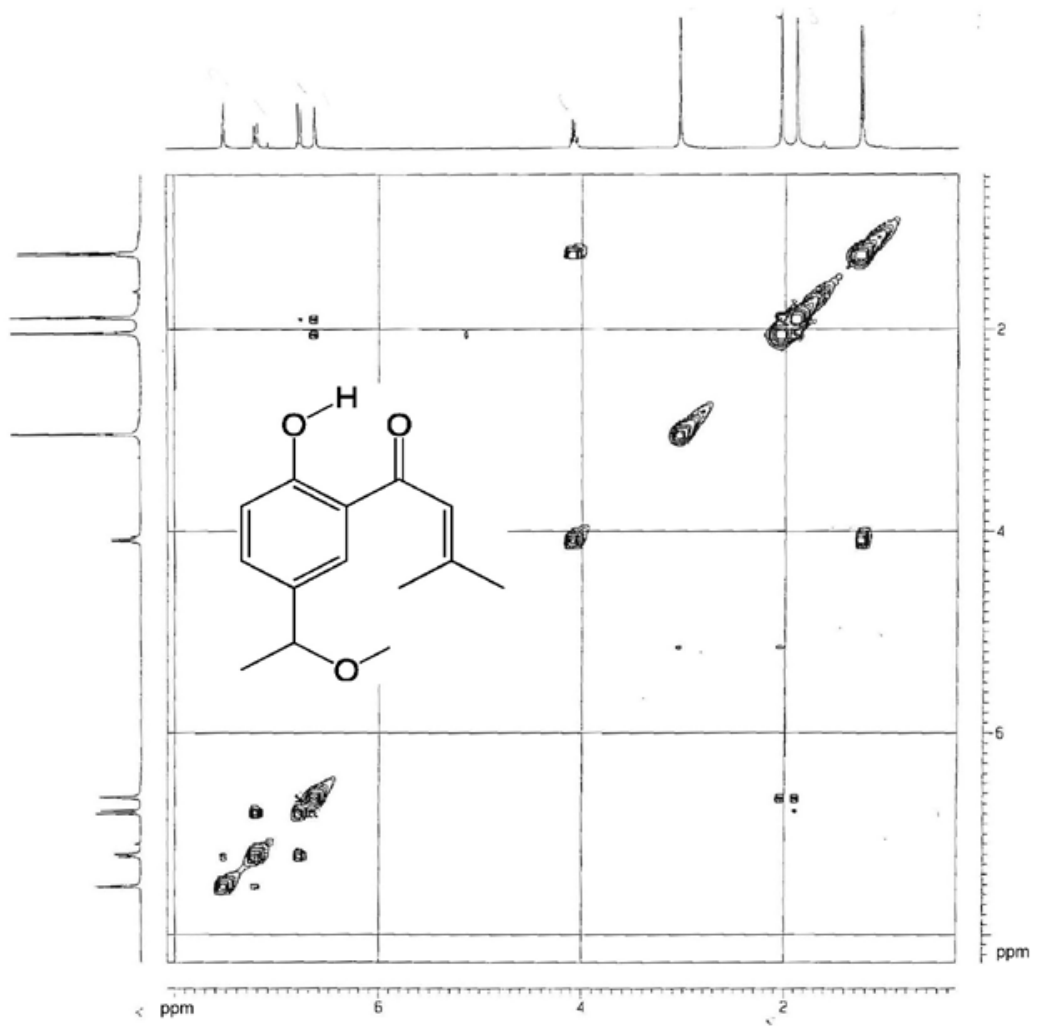

Figure S5. COSY NMR spectrum $\left(\mathrm{CDCl}_{3}\right)$ of compound $\mathbf{1}$. 


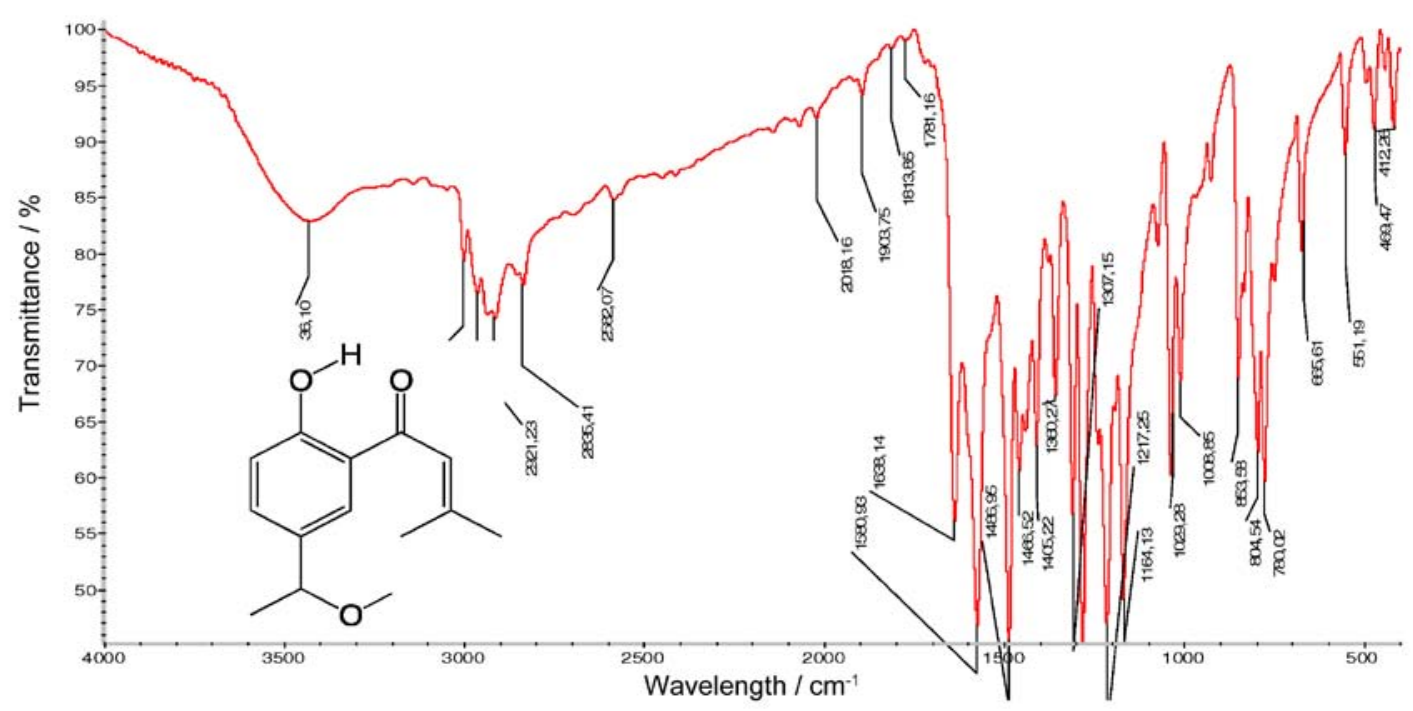

Figure S6. IR spectrum $(\mathrm{KBr})$ of compound $\mathbf{1}$.
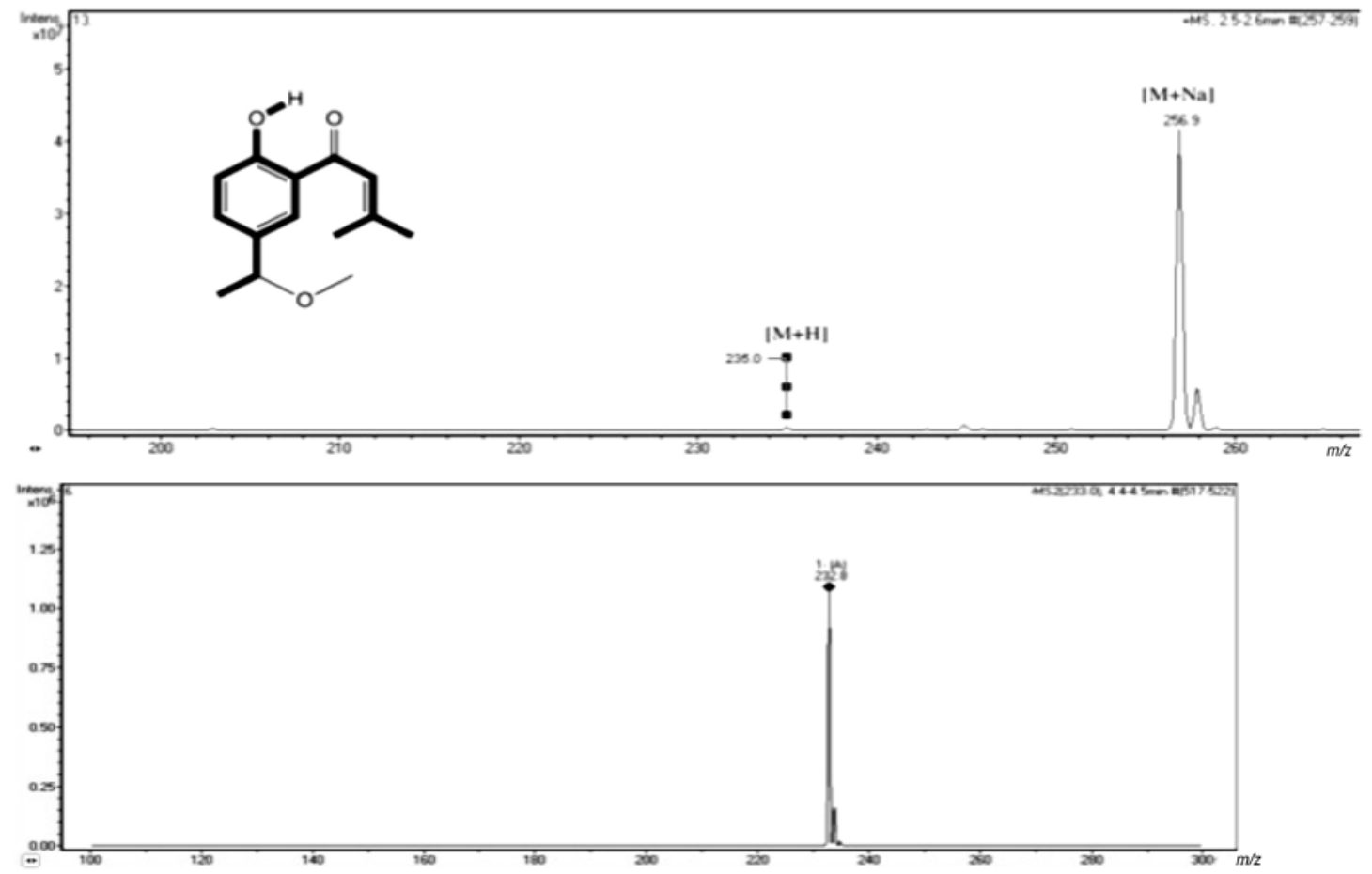

Figure S7. Mass spectra compound 1, top: positive mode, down: negative mode. 

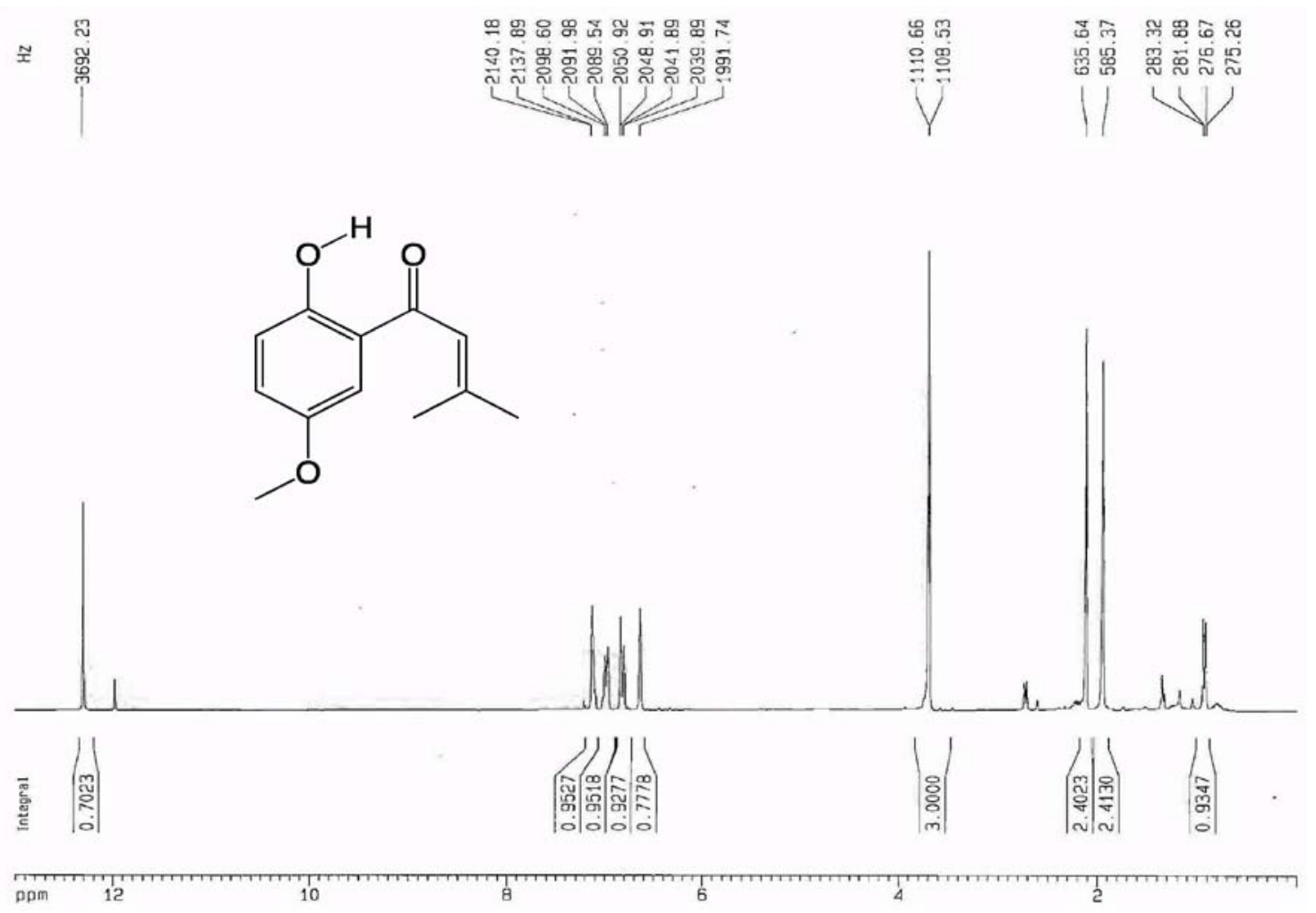

Figure S8. ${ }^{1} \mathrm{H}$ NMR spectrum $\left(\mathrm{CDCl}_{3}\right)$ of compound 2.
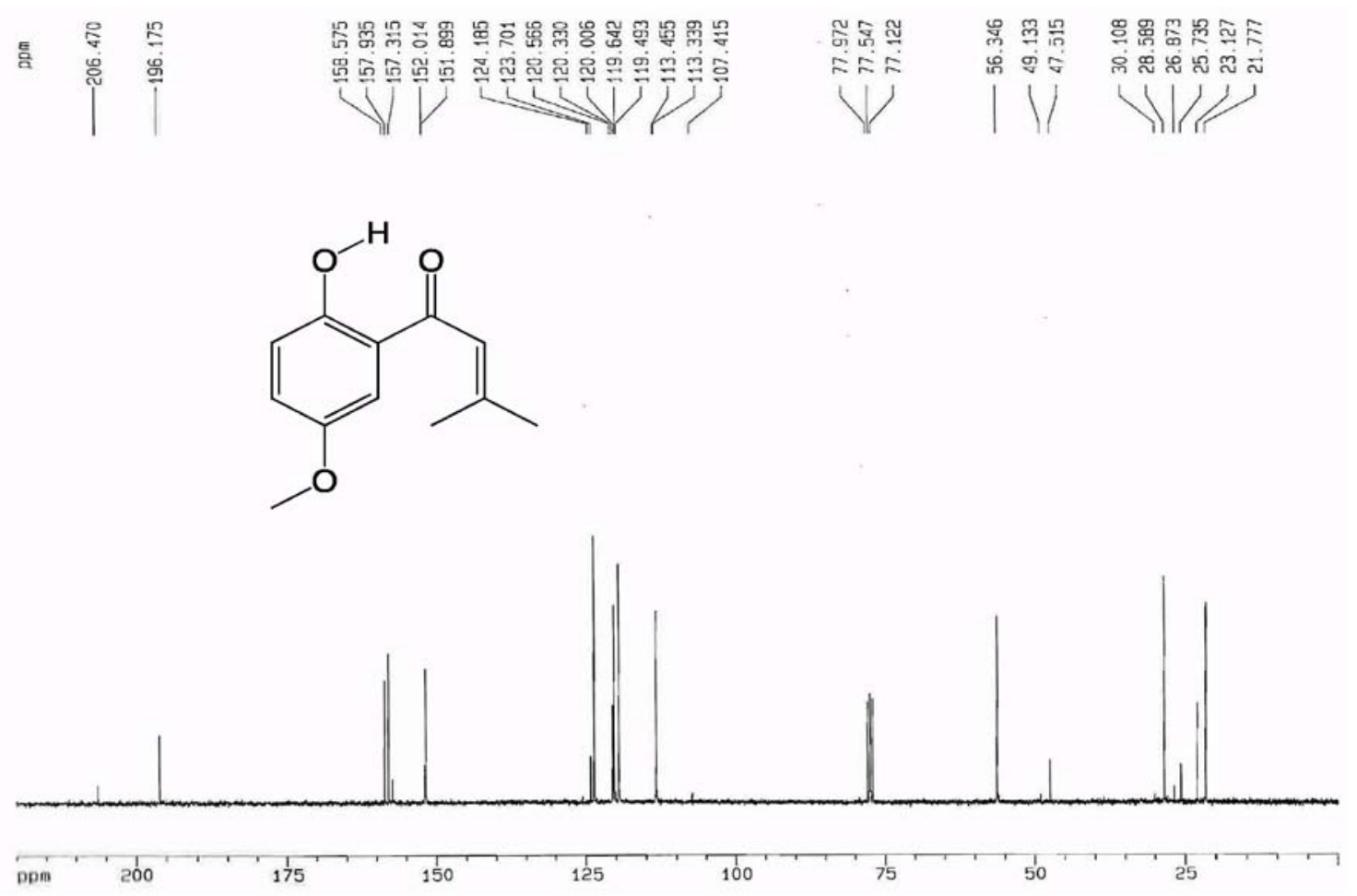

Figure S9. ${ }^{13} \mathrm{C}$ NMR spectrum $\left(\mathrm{CDCl}_{3}\right)$ of compound 2. 


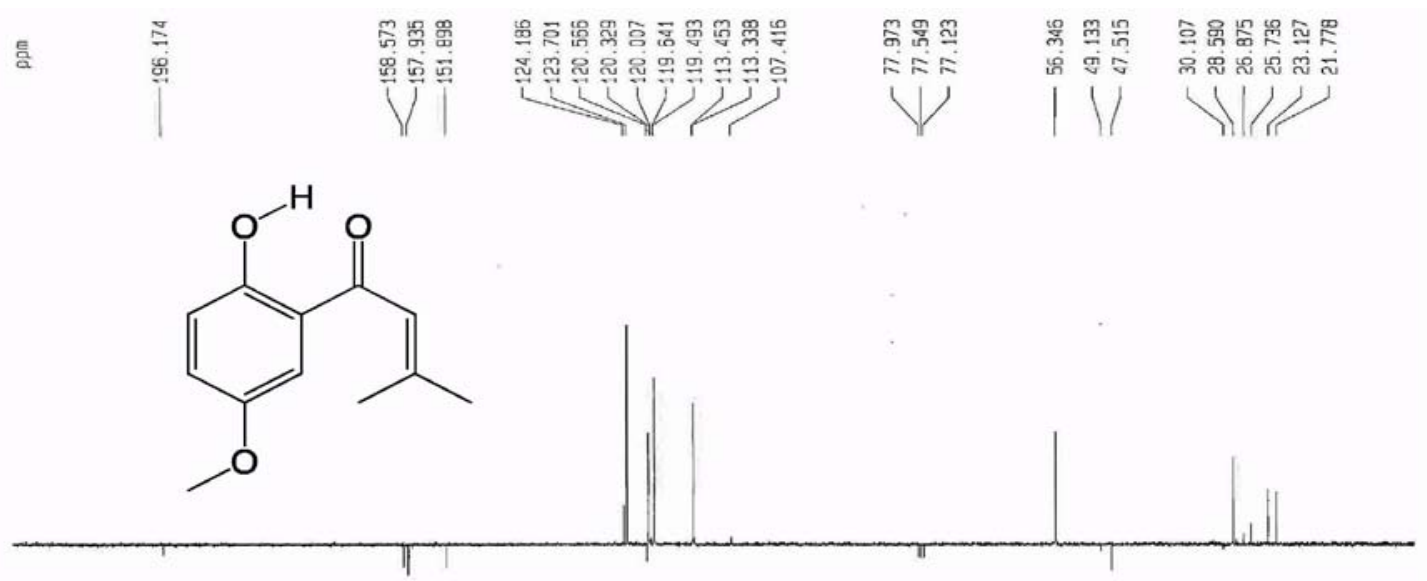

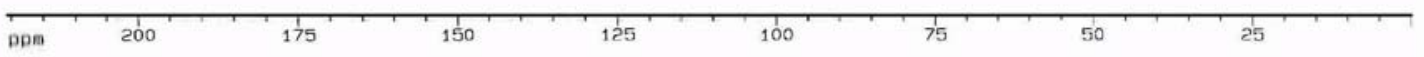

Figure S10. J-MOD NMR spectrum $\left(\mathrm{CDCl}_{3}\right)$ of compound 2 .

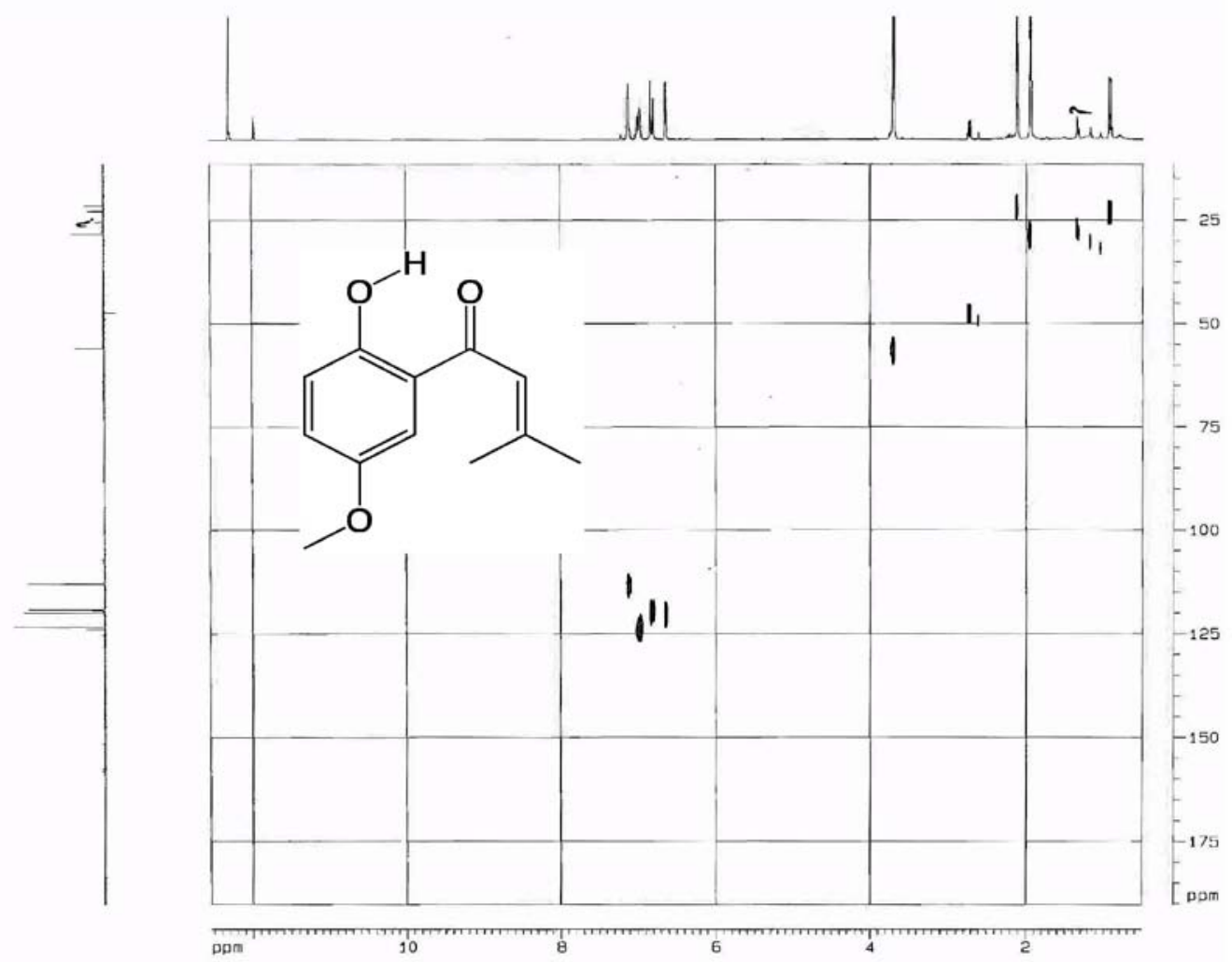

Figure S11. HMQC NMR spectrum $\left(\mathrm{CDCl}_{3}\right)$ of compound 2. 


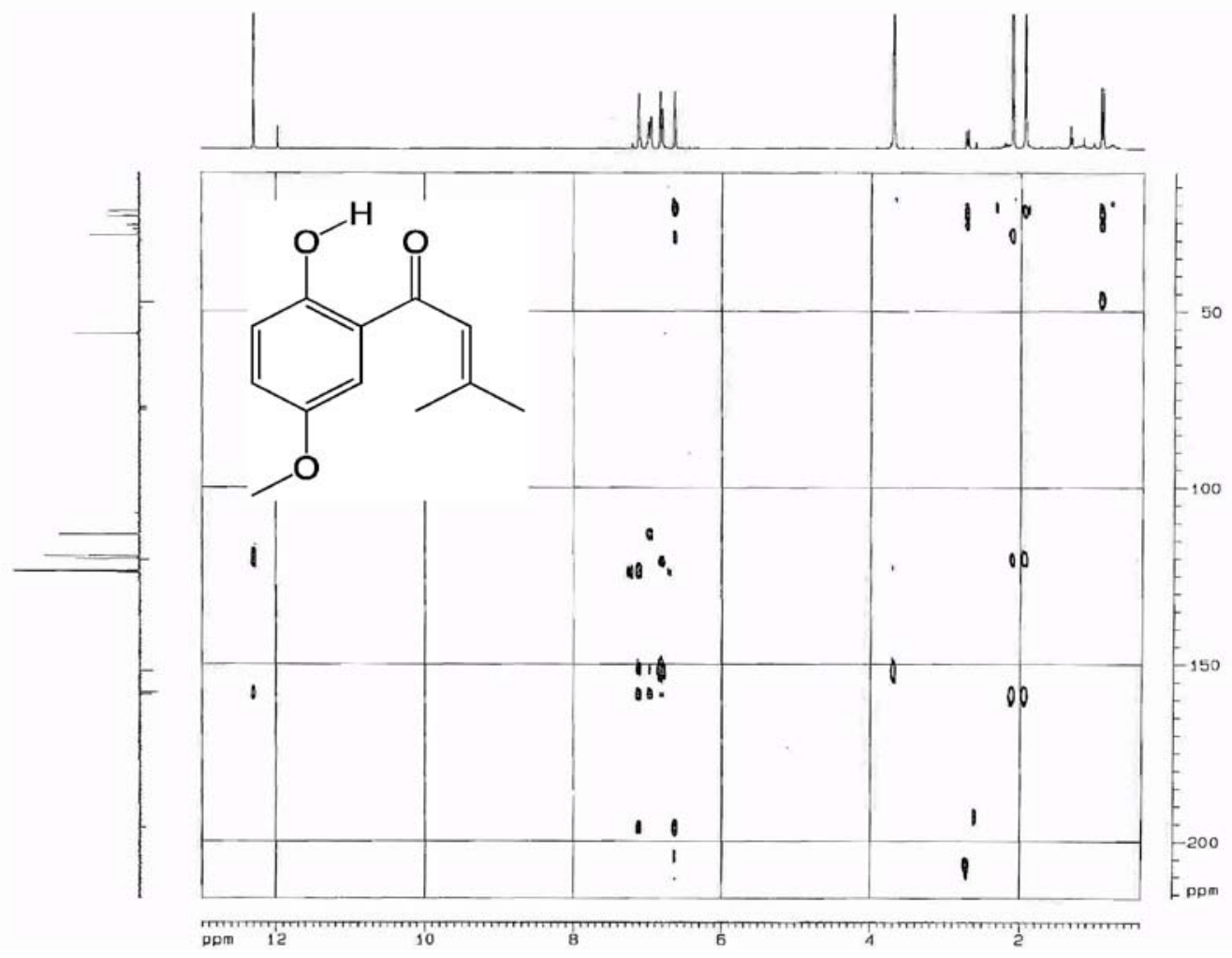

Figure S12. HMBC NMR spectrum $\left(\mathrm{CDCl}_{3}\right)$ of compound 2.

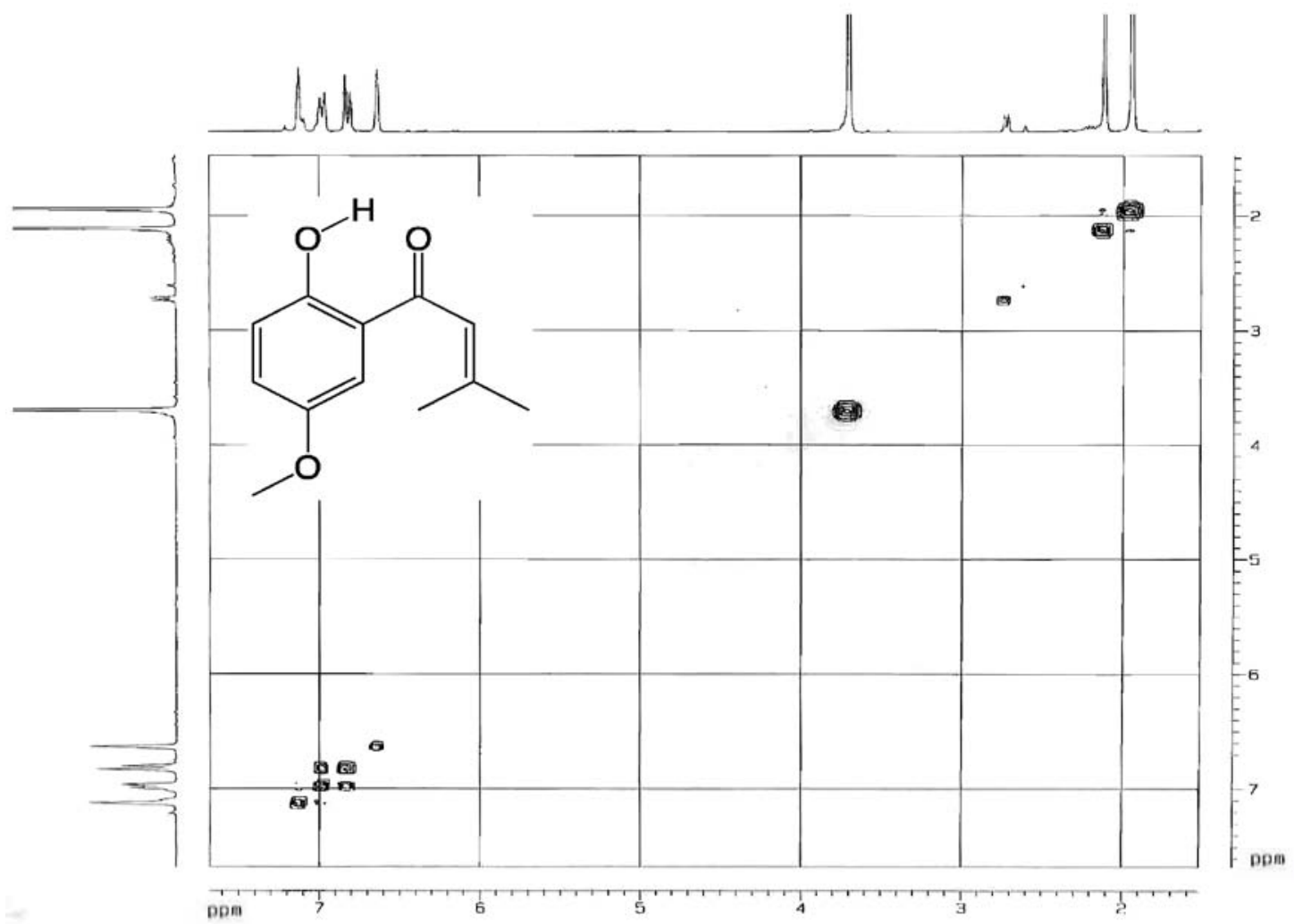

Figure S13. COSY NMR spectrum $\left(\mathrm{CDCl}_{3}\right)$ of compound 2. 


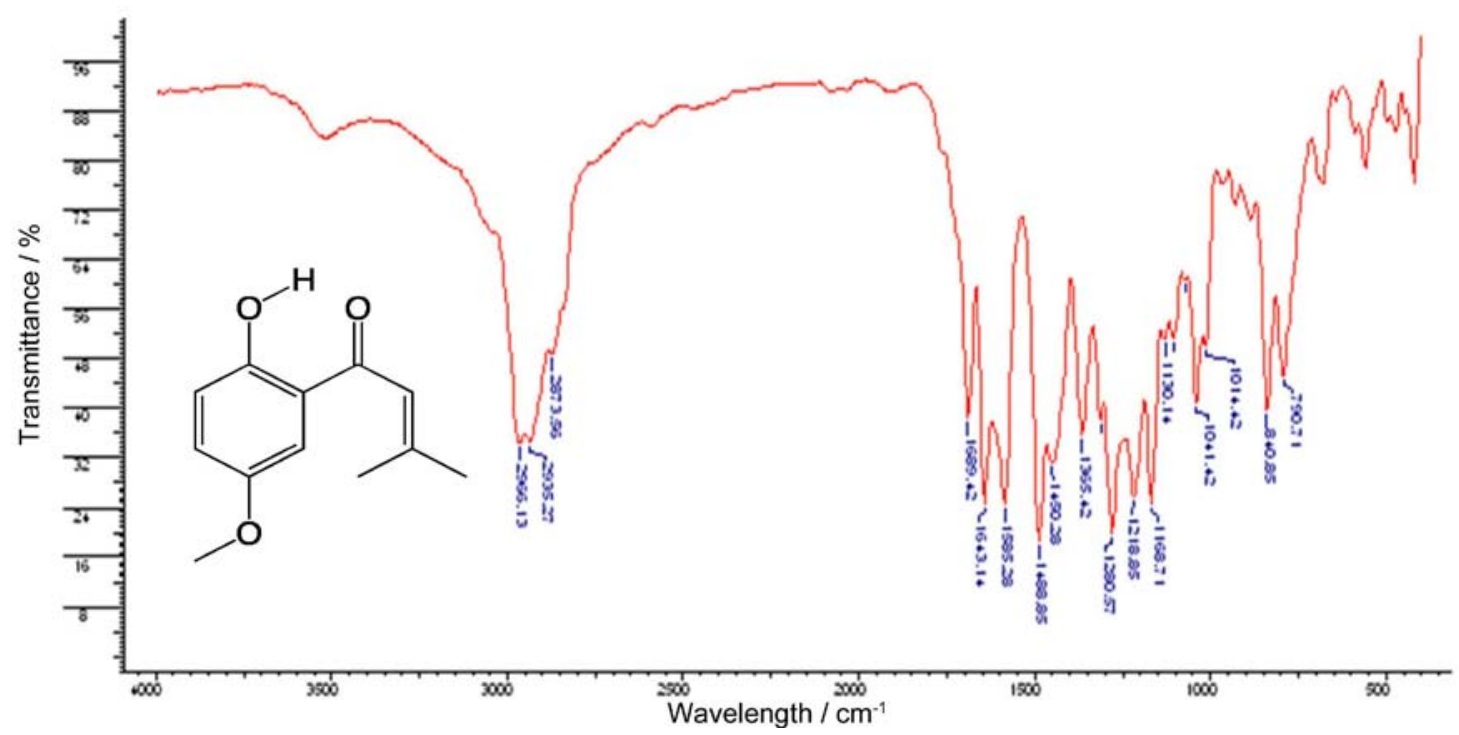

Figure S14. IR spectrum (KBr) of compound 2.
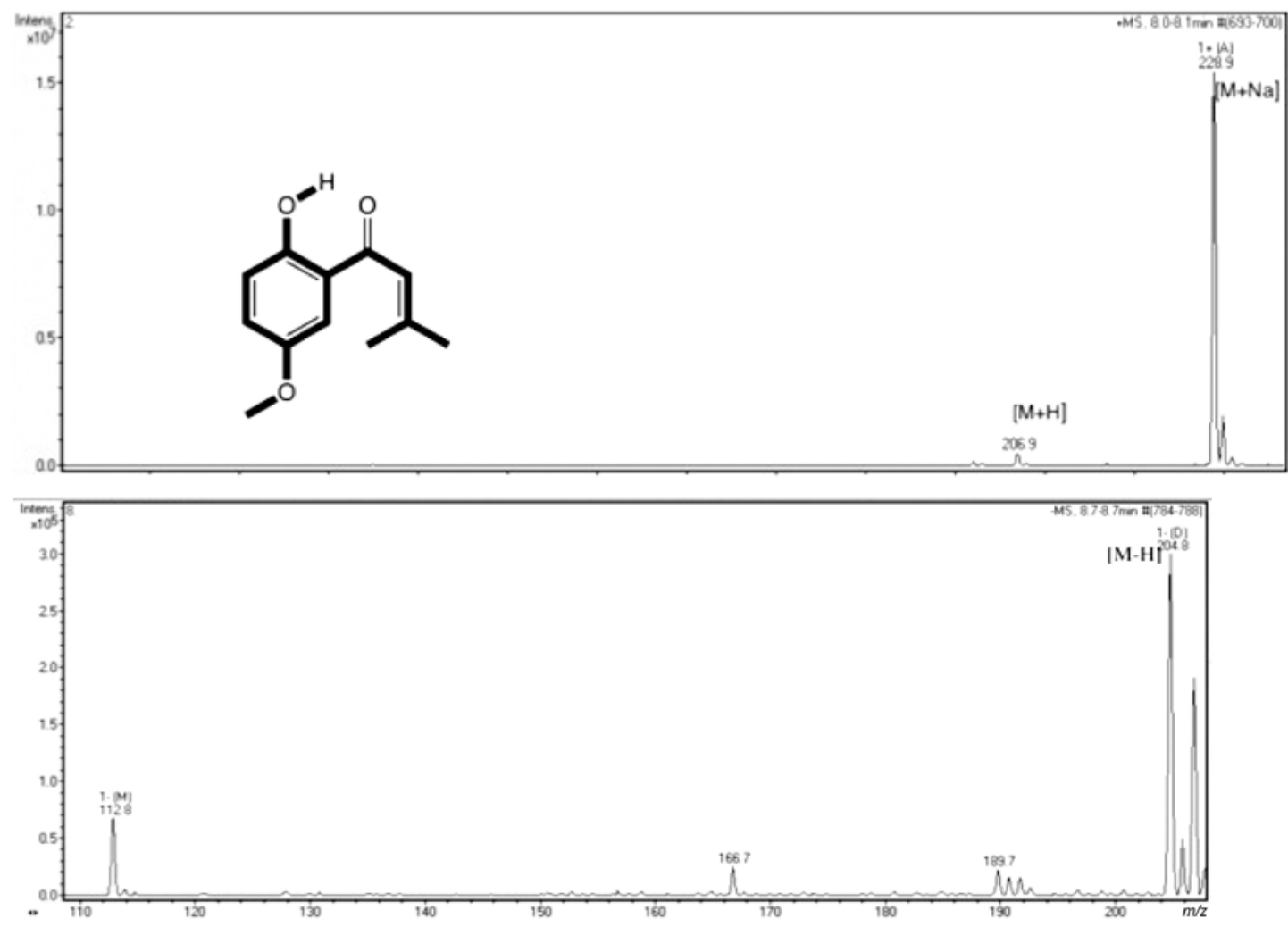

Figure S15. Mass spectra compound 2, top: positive mode, down: negative mode. 